\title{
A Comparison Study of Water Quality among Different Regions of Sharjah and Ajman in the United Arab Emirates
}

\author{
Sabrina Chelli, Adnan Falah, Rami El Khatib \\ School of Environment and Health Sciences, Canadian University of Dubai, \\ P.O. Box 117781, 1st Interchange, Sheikh Zayed Road, \\ Dubai, United Arab Emirates \\ rami@cud.ac.ae
}

\begin{abstract}
A comparison study of water quality among different regions of two major cities in UAE, Sharjah and Ajman, was undertaken. Numerous water samples were collected from five regions of Ajman and four regions of Sharjah near human activity areas, entertainment areas and industrial areas. The samples were taken approximately 10-20 meters from the shoreline, where the depth was 0.5-1.0 meter. Various tests were conducted to identify the levels of inorganic substances and physico-chemical parameters to determine if they were within an acceptable range for living organisms. Based on the analyzed data, the $\mathrm{pH}$ was relatively acidic, where it ranged between 5 and 6. Salinity average was 30,886 $\mu \mathrm{s} / \mathrm{cm}$. Total dissolved solids' (TDS) average was around $58,275 \mathrm{mg} / \mathrm{L}$, and the specific conductance average was about $75,356 \mu \mathrm{s} / \mathrm{cm}$. Many other inorganic substances involving $\mathrm{PO}_{4}{ }^{3-}, \mathrm{P}, \mathrm{P}_{2} \mathrm{O}_{5}, \mathrm{Fe}^{3+}$, $\mathrm{Cu}^{2+}, \mathrm{SO}_{4}{ }^{2-}, \mathrm{Br}^{-}, \mathrm{NO}_{3}{ }^{-}$, and $\mathrm{NO}_{3}{ }^{-}$as nitrogen, were also analysed to determine the impact of human activity on water quality. Some of the data collected for such parameters have showed low concentrations which is an indicator for desirable level of pollution.
\end{abstract}

Keywords: Water quality, pH, TDS, physico-chemical parameters, Sharjah, Ajman, UAE.

(C) Copyright 2014 Authors - This is an Open Access article published under the Creative Commons Attribution License terms http://creativecommons.org/licenses/by/3.0). Unrestricted use, distribution, and reproduction in any medium are permitted, provided the original work is properly cited.

\section{Introduction}

Water is a crucial compound for humanity $[1,2]$. However, Dubai's hot and arid climate prevents us from having readily available natural fresh water with rain only few days in a month per year. It is then imperative for the UAE to find a way around this knowing that they have one of the highest water footprints ("the average resident's 550 litres a day for drinking and washing are more than triple the world average") [3] yet have little fresh water available. With today's advanced technology, there are a few methods available to increase the supply of fresh water, either from sea water or from underground aquifers. Desalination and reverse osmosis are two ways to address this issue [4]. However there are some limitations to those methods. Reverse osmosis requires high pressure which is very expensive. Desalination is also costly because the pumps require a lot of power and energy. Jebel Ali is known to have one of the largest desalination industries which also harm the environment by draining sea water from oceans and by pumping it back in, often too concentrated in salts and other inorganic species.

UAE has significantly changed in the last ten years due to the construction of buildings, artificial islands, chemical industries and port activities [4]. Furthermore, these activities have negatively impacted the natural environment, particularly the water. In this report, the effect of the surrounding environment on the water quality in several industrial, human activity and entertainment areas in Sharjah and Ajman will be investigated and discussed.

Nine water samples were collected and analyzed from several locations in Sharjah and Ajman, UAE. They were subjected to water analysis to determine the concentration of inorganic substances such as $\mathrm{Fe}^{2+}$, $\mathrm{Cu}^{2+}, \mathrm{PO}_{4}{ }^{3-}, \mathrm{P}$ and $\mathrm{P}_{2} \mathrm{O}_{5}$ and physico-chemical parameters like $\mathrm{pH}$, TDS (total dissolved solids), EC (electrical conductivity) and salinity [5]. 


\section{Materials and Methods}

\subsection{Chemicals and Instruments}

The analysis of water samples was done using the HI 83200 Multiparameter Bench Photometer and the reagents from "HANA Spectroquant kit" [4].

Every water sample was filtered at first using filter paper. The photometer can measure certain concentration range $(0-2000 \mathrm{mg} / \mathrm{L})$, in case of sea water, high concentration substances. Thus in order to determine the exact concentration the water sample should be diluted first; and then analyzed in which $99 \mathrm{~mL}$ of distilled water was added to $1 \mathrm{~mL}$ of the water sample and was then multiplied by 100 .

The tests conducted involved determining the concentration of inorganic substances such as $\mathrm{Fe}^{3+}$, $\mathrm{Cu}^{2+}, \mathrm{PO}_{4}{ }^{3-}, \mathrm{P}$ and $\mathrm{P}_{2} \mathrm{O}_{5}$ and also physico-chemical tests which involved electrical conductivity, $\mathrm{pH}$, TDS (total dissolved solids) and salinity [4]. All water samples were analyzed at the same time after collection and were stored under dry conditions at $25^{\circ} \mathrm{C}$. The samples were collected about 10-20 meters from the shore at depth of 0.5-1 meters.

\section{Results and Discussion}

The water samples studied were taken from Sharjah as shown in table 1 and from Ajman as shown in table 2 .

Table 1. Beaches analyzed from Sharjah and their surrounding environment.

\begin{tabular}{|c|c|c|c|}
\hline $\begin{array}{l}\text { Number } \\
\text { of the } \\
\text { Beach }\end{array}$ & $\begin{array}{l}\text { Name of } \\
\text { Beach }\end{array}$ & City & $\begin{array}{l}\text { Surrounding } \\
\text { Environment }\end{array}$ \\
\hline 1 & $\begin{array}{c}\text { Kanat Al } \\
\text { Qasha }\end{array}$ & Sharjah & $\begin{array}{l}\text { Entertainment area, } \\
\text { jet ski activity, next } \\
\text { to coral reefs. }\end{array}$ \\
\hline 2 & $\begin{array}{l}\text { Tawan } \\
\text { next to } \\
\text { Mamzar }\end{array}$ & Sharjah & $\begin{array}{l}\text { Entertainment area, } \\
\text { jet ski activity, next } \\
\text { to coral reefs. }\end{array}$ \\
\hline 3 & $\begin{array}{c}\text { Golden } \\
\text { Gate Hotel } \\
\text { beach } \\
\text { area }\end{array}$ & Sharjah & $\begin{array}{c}\text { Industrial area, next } \\
\text { to Zulal water } \\
\text { bottling \& electricity } \\
\text { industry }\end{array}$ \\
\hline 4 & Nayya & Sharjah & $\begin{array}{l}\text { Human activity } \\
\text { area, port }\end{array}$ \\
\hline
\end{tabular}

Table 2. Beaches analyzed from Ajman and their surrounding environment.

\begin{tabular}{|c|c|c|c|}
\hline $\begin{array}{c}\text { Number } \\
\text { of the } \\
\text { beach }\end{array}$ & $\begin{array}{c}\text { Name of } \\
\text { Beach }\end{array}$ & City & $\begin{array}{c}\text { Surrounding } \\
\text { Environment }\end{array}$ \\
\hline 5 & Port Ajman & Ajman & $\begin{array}{c}\text { Human activity } \\
\text { area, port }\end{array}$ \\
\hline 6 & Corniche & Ajman & $\begin{array}{c}\text { Entertainment } \\
\text { area, beach club }\end{array}$ \\
\hline 7 & $\begin{array}{c}\text { Ajman } \\
\text { beach }\end{array}$ & Ajman & $\begin{array}{c}\text { Entertainment } \\
\text { area, Dana Beach } \\
\text { Hotel }\end{array}$ \\
\hline 8 & $\begin{array}{c}\text { Al } \\
\text { Muntazah }\end{array}$ & Ajman & $\begin{array}{c}\text { Human activity } \\
\text { area, fishing port }\end{array}$ \\
\hline 9 & $\begin{array}{c}\text { Beginning } \\
\text { of Corniche }\end{array}$ & Ajman & $\begin{array}{c}\text { Entertainment } \\
\text { area, beach }\end{array}$ \\
\hline
\end{tabular}

\subsection{Characterization of Sea Water}

The phosphate concentrations were found to be within normal range (as they are all low) in all beaches with the exception of Al Muntazah and Tawan next to Mamzar (Table 3) as their phosphate concentrations were slightly higher than the other beaches; and the industry in Sharjah with the beginning of the Corniche of Ajman which had a very low presence of phosphate. The beginning of the Corniche of Ajman indicated negative tests for all three phosphate groups representing a low pollution level. Considering its surroundings of hardly any human activity, it isn't surprising that there are no indications of pollution. However, the fact that phosphate isn't present in water signifies that it is the limiting factor for algal growth. Low concentrations in the water next to the industry in Sharjah were unexpected as contaminated water often has high phosphate levels. Since it was in an acceptable range, the industry seems to manage well since the phosphate levels were low.

Al Muntazah and Tawan however, indicated higher levels of phosphate compared to the other beaches showing a slightly polluted area. There could have been many factors causing that such as "decaying plant matter, fertilizers, mineral treatment chemicals, contaminated well water, acid rain, contamination with soil, ground water runoff, bird droppings, bather wastes, urine and sweat" [6]. Nevertheless in the case of Al Muntazah, the most apparent factors are due to human activity practiced in presence of a fishing port. Moreover, when the sample was collected, the water 
had an orangey colour to it which already gave a first impression of pollution.

The copper range in water (Table 3) should not exceed more than $1 \mathrm{mg} / \mathrm{L}$ [7] as it may cause vomiting and liver damage. In general, it is not seen as a health hazard if in a low concentration. The results below for all 9 beaches indicate low concentrations of copper under $1 \mathrm{mg} / \mathrm{L}$.

Iron concentrations should not exceed $0.1-0.3 \mathrm{mg} / \mathrm{L}$ [8] in drinkable water. If exceeded, it may cause gastrointestinal problems, heart diseases and sometimes cancer. Seawater should normally contain less than 1.5 to $2 \mathrm{mg} / \mathrm{L}$ [8] of iron. The results for iron (Table 3) are all under the abnormal range with the exception of Port Nayya (sample 4), water next to Zulal water \& electricity industry (sample 3) and the beginning of the Corniche of Ajman (sample 9) which are a little bit higher than the others. The reason why iron was slightly higher in Port Nayya could be due to the commercial shipping of goods and the activity may lead to iron corrosion in water. Since sample 3 was collected next to an industry in Sharjah, it was anticipated that the iron level would be slightly higher than the others. Lastly, sample 9 wasn't expected to have a level of iron as high as sample 3 and 4 . But since it was an entertainment area linked to Jet Ski activity, the saltwater could have caused the jet skis to corrode which could be the justification for this cause.

The $\mathrm{pH}$ range of the seawater should be 7.5 to 8.5 $[9,10]$. The $\mathrm{pH}$ of all the water samples (Table 3 ) is between 5 and 6 which is slightly acidic. However, beaches 1 and 2 have a slightly more acidic $\mathrm{pH}$ than the other beaches. In general, low $\mathrm{pH}$ levels are caused by dissolved carbon dioxide and acid generated salts [4]. This can be potentially harmful to the marine life, particularly those that are adapted to live in water of neutral $\mathrm{pH}$.

The normal range of salinity is about 33 to $37 \mathrm{ppt}$ $[11,12]$. The data collected (Table 3 ) respects the range of salinity except for the fishing boat area at $\mathrm{Al}$ Muntazah and the beginning of Corniche of Ajman with lower results of 23 and $29 \mathrm{ppt}$. This means that the sum of solid materials in the water is lower than the normal range. Low salinity may slowly kill corals and other marine creatures present in the water which are sensitive to salinity concentration changes [5]. This may be a point to consider in a long term aspect.
The total dissolved solids' normal seawater range should be 30,000-40,000 ppm [13]. All the beaches have an extremely high range of TDS as they all exceed $40,000 \mathrm{ppm}$ (Table 3). These high concentrations of dissolved solids show that the human activity is dominant in the UAE (construction sites, chemical industries...). It also implies a hazard for marine life. We have noticed that the $\mathrm{pH}$, salinity and the TDS ranges in most samples have shown compatible values with the exception of sample 8 which had revealed a higher $\mathrm{pH}$ value. This may be due to higher values of alkaline earth metals $\left(\mathrm{Ca}^{2+}\right.$ and $\left.\mathrm{Mg}^{2+}\right)$ that were not studied in this report. The values of specific conductance [10] amongst different water samples have shown variations that can be due to the fact that some ions may exist in two different forms as either free or complex.

Seawater contains about $2700 \mathrm{mg} / \mathrm{L}$ of Sulfate [14]. Most of the beaches (Table 4) are around that range with the exception of Kanat Al Qasha in Sharjah, Port Nayya in Sharjah and the fishing boat area at $\mathrm{Al}$ Muntazah in Ajman. The concentration of Sulfate in seawater depends upon the discharge from the soil and the rocks present as well as the leakage of sewers, precipitation and other [8]. The concentration in Kanat Al Qasha and Port Nayya are slightly higher with a concentration of $3000 \mathrm{mg} / \mathrm{L}$ whereas the boat area in $\mathrm{Al}$ Muntazah is low with a concentration of $2000 \mathrm{mg} / \mathrm{L}$. Higher concentrations of Sulfate may indicate higher levels of pollution from leakage of toxic substances or simply high rates of discharge from the soil and the rocks [4].

A normal range of Bromide in seawater is within a range of $65 \mathrm{mg} / \mathrm{L}$ to $80 \mathrm{mg} / \mathrm{L} \mathrm{[15]} \mathrm{and} \mathrm{a} \mathrm{suitable} \mathrm{range}$ for bromine is about $70 \mathrm{ppm}$ [16] which is around 69.92 $\mathrm{mg} / \mathrm{L}$. The concentration of bromine in all the beaches (Table 4) was found to be very low if not, non-existent in some cases with concentrations of $0.00-0.25 \mathrm{mg} / \mathrm{L}$. Nitrate concentrations should not exceed $5 \mathrm{ppm}$ in seawater as it could cause severe problems and toxicity in plants [8]. All beaches (Table 4) did not exceed this range with the exception of Al Muntazah in Ajman. The concentration found in this area was $12.5 \mathrm{mg} / \mathrm{L}$ which greatly exceeded the appropriate range. This high level of toxicity presents a hazard for aquatic plants and indicates a high level of pollution [4]. 
Table 3. Physico-Chemical analysis of the concentration of inorganic substances and properties in several areas in Ajman and Sharjah, samples 1-9 (in mg/L).

\begin{tabular}{|c|c|c|c|c|c|c|c|c|c|c|c|}
\hline $\begin{array}{l}\text { Sample } \\
\text { number }\end{array}$ & Beach & Location & $\mathrm{pH}$ & $\begin{array}{c}\text { Specific } \\
\text { Conductance } \\
\text { (usicm) }\end{array}$ & $\begin{array}{l}\text { Salinity } \\
(\mu \mathrm{s} / \mathrm{cm})\end{array}$ & $\begin{array}{c}\text { Total } \\
\text { Dissolved } \\
\text { Solid } \\
\text { (TDS) }\end{array}$ & $\begin{array}{l}\text { Phosphate } \\
\left(\mathrm{PO4}^{2}\right)\end{array}$ & $\begin{array}{l}\text { Phosphorus } \\
\text { (P) }\end{array}$ & $\begin{array}{c}\text { Phosphorus } \\
\text { Pent aoxide } \\
\left(\mathrm{P}_{2} \mathrm{O}_{3}\right)\end{array}$ & $\begin{array}{l}\text { Iron } \\
\left(\mathrm{Fe} \mathrm{e}^{\mathrm{s}+)^{\prime}}\right)\end{array}$ & $\begin{array}{c}\mathrm{Cu}^{2+} \\
(\mu \mathrm{gL})\end{array}$ \\
\hline \multicolumn{3}{|c|}{ Standard Value } & $7.5-8.5$ & 54,000 & $33-37$ & $\begin{array}{l}30,000- \\
40,000 \\
(\mathrm{ppm})\end{array}$ & 5 & 5 & 5 & $0.1-0.3$ & $\begin{array}{c}<1 \\
(\mathrm{mg} / \mathrm{L})\end{array}$ \\
\hline 1 & $\begin{array}{c}\text { Kanat A1 } \\
\text { Qasha }\end{array}$ & Sharjah & 5.69 & 58,500 & 31,563 & 59,552 & 0.4 & 0.1 & 0.3 & 0.00 & 369 \\
\hline 2 & $\begin{array}{c}\text { Tawan } \\
\text { next to } \\
\text { Mamzar }\end{array}$ & Sharjah & 5.68 & 80,000 & 31,642 & 59,702 & 1.4 & 0.5 & 1.1 & 0.04 & 173 \\
\hline 3 & $\begin{array}{l}\text { Next to } \\
\text { Zalal } \\
\text { water \& } \\
\text { electricity } \\
\text { industry }\end{array}$ & Shagiah & 5.75 & 79,100 & 31,721 & 59,851 & 0.1 & 0.0 & 0.1 & 0.00 & 430 \\
\hline 4 & $\begin{array}{c}\text { Port } \\
\text { Nayya }\end{array}$ & Sharjah & 5.58 & 81,000 & 32,670 & 61,641 & 0.5 & 0.1 & 0.3 & 0.1 & 422 \\
\hline 5 & $\begin{array}{l}\text { Ajman } \\
\text { Port } \\
\text { beside the } \\
\text { creek of } \\
\text { Ajman }\end{array}$ & Ajman & 5.89 & 86,500 & 34,094 & 64,328 & 1.0 & 0.3 & 0.8 & 0.01 & 262 \\
\hline 6 & $\begin{array}{l}\text { Comiche } \\
\text { of Ajman }\end{array}$ & Ajman & 5.69 & 82,000 & 32,591 & 61,493 & 0.8 & 0.3 & 0.6 & 0.04 & 219 \\
\hline 7 & $\begin{array}{l}\text { Ajman } \\
\text { Beach }\end{array}$ & Ajman & 5.64 & 78,100 & 31,009 & 58,508 & 1.0 & 0.3 & 0.7 & 0.03 & 218 \\
\hline 8 & $\begin{array}{c}\text { Fishing } \\
\text { boat area } \\
\text { at } \mathrm{Al} \\
\text { Muntazah }\end{array}$ & Ajman & 6.11 & 58,500 & 23,099 & 43,582 & 2.0 & 0.7 & 1.5 & 0.05 & 224 \\
\hline 9 & $\begin{array}{l}\text { Beginning } \\
\text { of } \\
\text { Comiche } \\
\text { of Ajman }\end{array}$ & Ajman & 5.63 & 74,500 & 29,585 & 55,821 & 0.0 & 0.0 & 0.0 & 0.06 & 419 \\
\hline
\end{tabular}

Table 4. Physico-Chemical analysis of the concentration of inorganic substances and properties in several areas in Ajman and Sharjah, samples 1-9 (in mg/L).

\begin{tabular}{|c|c|c|c|c|c|c|}
\hline $\begin{array}{l}\text { Sample } \\
\text { number }\end{array}$ & Beach & Location & $\begin{array}{l}\text { Sulfate } \\
\text { (SO4?) }\end{array}$ & $\begin{array}{l}\text { Bromine } \\
\text { (Br2) }\end{array}$ & $\begin{array}{l}\text { Nitrate } \\
\text { (NOB) }\end{array}$ & $\begin{array}{l}\text { Nitrate- } \\
\text { Nitrogen } \\
\text { (NOs--N) }\end{array}$ \\
\hline \multicolumn{3}{|c|}{ Standard Value } & 2700 & $65-80$ & $<5$ & $<3$ \\
\hline 1 & $\begin{array}{c}\text { Kanat A1 } \\
\text { Qasha }\end{array}$ & Sharjah & 3,000 & 0.25 & 0.0 & 0.0 \\
\hline 2 & $\begin{array}{c}\text { Tawan } \\
\text { next to } \\
\text { Mamzar }\end{array}$ & Sharjah & 2,500 & 0.00 & 0.0 & 0.0 \\
\hline 3 & $\begin{array}{c}\text { Next to } \\
\text { Zalal } \\
\text { water \& } \\
\text { electricity } \\
\text { industry }\end{array}$ & Sharjah & 2,500 & 0.00 & 0.0 & 0.0 \\
\hline 4 & $\begin{array}{c}\text { Port } \\
\text { Nayya }\end{array}$ & Sharjah & 3,000 & 0.10 & 0.0 & 0.0 \\
\hline 5 & $\begin{array}{c}\text { Ajman } \\
\text { Port } \\
\text { beside the } \\
\text { creek of } \\
\text { Ajman }\end{array}$ & Ajman & 2,500 & 0.11 & 2.4 & 0.5 \\
\hline 6 & $\begin{array}{l}\text { Comiche } \\
\text { of Ajman }\end{array}$ & Ajman & 2,500 & 0.03 & 0.0 & 0.0 \\
\hline 7 & $\begin{array}{l}\text { Ajman } \\
\text { Beach }\end{array}$ & Ajman & 2,500 & 0.22 & 0.0 & 0.0 \\
\hline 8 & $\begin{array}{c}\text { Fishing } \\
\text { boat area } \\
\text { at } \mathrm{Al} \\
\text { Muntazah }\end{array}$ & Ajman & 2,000 & 0.03 & 12.5 & 2.8 \\
\hline 9 & $\begin{array}{c}\text { Beginning } \\
\text { of }\end{array}$ & Ajman & 2,500 & 0.08 & 1.7 & 0.4 \\
\hline
\end{tabular}




\section{Conclusion}

Human activity has a fairly important impact on the water quality as seen with a high range in phosphates in entertainment and industrial areas. Based on the analysis of the results, Port Nayya as well as water collected next to the industry in Sharjah and the beginning of the Corniche of Ajman had higher iron content due to the port activity and industrial activity leading to corrosion and other negative impacts. The electrical conductivity and the salinity were found to be within an acceptable range which is a good indication for low pollution levels except for the fishing boat area where salinity ranges were little bit lower than normal which may be a point to consider in a long term aspect. However, the high TDS levels do imply dominant human activities increasing the risk of future high pollution levels if practiced over a long period of time. Many other inorganic substances involving $\mathrm{PO}_{4}{ }^{3-}, \mathrm{P}, \mathrm{P}_{2} \mathrm{O}_{5}$, $\mathrm{Fe}^{3+}, \mathrm{Cu}^{2+}, \mathrm{SO}_{4}{ }^{2-}, \mathrm{Br}^{-}, \mathrm{NO}_{3}{ }^{-}$, and $\mathrm{NO}_{3}{ }^{-}$as nitrogen, were also analysed to determine the impact of human activity on water quality. Even though the seawaters are not highly polluted with the analyzed parameters, the $\mathrm{pH}$ is relatively low compared to the normal range. This implies that the acidity levels caused by dissolved carbon dioxide or acid generated salts are relatively high. This would be something interesting to look at in the near future because acidic water conditions may represent a threat to marine life. In order to draw a clear conclusion on how surroundings affect the water quality, further studies may be needed to look at the interactions between the different physico-chemical parameters and the biotic factors (marine organisms and plants).

\section{Acknowledgment}

The authors would like to acknowledge Ms. Zena Muhtaseb for her help and support throughout this study.

\section{References}

[1] R.H. Friis "Essentials of Environmental Health" Sudbury, USA: Jones \& Bartlett learning, 2012.

[2] G.T. Miller and S. Spoolman "Environmental Science" Mississauga, Canada: Thomson, 2008.

[3] M. Kwong, "You're looking at 140 litres of water" [Online] Available: http://www.thenational.ae/news/uaenews/s cience/youre-looking-at-140-litres-of-water.

[4] R. El Khatib, A. Falah, G. Tavakoli, C. D'cruz and J. Pereira "A Study of Water Quality Near to a Coral
Reef Site in the Region of Dubai, United Arab Emirates." Canadian Journal on Chemical Engineering \& Technology ,vol. 3, no.3, April 2012.

[5] A. Falah, R. El Khatib, N. Yahfoufi "Water Quality Survey of Arabian Peninsula in Regions of Dubai in the United Arab Emirates." Canadian Journal on Chemical Engineering \& Technology, vol. 3, no. 1, January 2012.

[6] Aqualab Systems Phosphate Problemsin Pools [Online]. 2011 Available: http://www.askalanaquestion.com/phosphate_poo l_problems.htm.

[7] J. D. Fitzgerald. "Safety guidelines for copper in water." The American Journal of Clinical Nutrition , 1998.

[8] H. H. Hammud, "Quality and Pollution Studies of Water in Lebanon", Ultra Science - Dimension of Pollution, 1, 19, 2001.

[9] G. Anderson "Seawater Composition." [Online] Available:http://www.marinebio.net/marinescienc e/02ocean/swcomposition.htm. 2008.

[10] E. Wenner "Water Quality" [Online] . Available: http://www.nerrs.noaa.gov/doc/siteprofile/aceba $\sin / \mathrm{html} /$ envicond/watqual/wqintro.htm 2012.

[11] R. Nave "Seawater" [Online] Available:http://hyperphysics.phyastr.gsu.edu/hbase/chemical/seawater.html. 2000.

[12] Apps Laboratories "Salinity - what do those figures mean?" [Online] Available: http://appslabs.com.au/salinity.htm. 2014.

[13] Water Quality Association "Water Classifications" [Online]. Availble: http://www.pacificro.com/watercla.htm. 2012.

[14] World Health Organization "Sulfate in Drinkingwater" 2004.

[15] A. Kabbani, H.H. Hammud, H. Itani "Spring Water of Lebanese Bekaa Valley". Ultra Science - Dimension of Pollution, 1, 48, 2001.

[16] Daat Solutions of ICL Group, "Bromine" [Online]. Available :http://icl-ip.com/?products=bromine. 2013. 